\title{
The contribution of the various phosphorylating steps in the respiratory chain to the dinitrophenol induced ATPase of rat-liver mitochondria
}

Citation for published version (APA):

Hemker, H. C. (1963). The contribution of the various phosphorylating steps in the respiratory chain to the dinitrophenol induced ATPase of rat-liver mitochondria. Biochimica et Biophysica Acta (BBA) - Specialized Section on Enzymological Subjects, 73(2), 311-323. https://doi.org/10.1016/0926-6569(63)90165-2

Document status and date:

Published: 11/06/1963

DOI:

10.1016/0926-6569(63)90165-2

Document Version:

Other version

Please check the document version of this publication:

- A submitted manuscript is the version of the article upon submission and before peer-review. There can be important differences between the submitted version and the official published version of record.

People interested in the research are advised to contact the author for the final version of the publication, or visit the DOI to the publisher's website.

- The final author version and the galley proof are versions of the publication after peer review.

- The final published version features the final layout of the paper including the volume, issue and page numbers.

Link to publication

\footnotetext{
General rights rights.

- You may freely distribute the URL identifying the publication in the public portal. please follow below link for the End User Agreement:

www.umlib.nl/taverne-license

Take down policy

If you believe that this document breaches copyright please contact us at:

repository@maastrichtuniversity.nl

providing details and we will investigate your claim.
}

Copyright and moral rights for the publications made accessible in the public portal are retained by the authors and/or other copyright owners and it is a condition of accessing publications that users recognise and abide by the legal requirements associated with these

- Users may download and print one copy of any publication from the public portal for the purpose of private study or research.

- You may not further distribute the material or use it for any profit-making activity or commercial gain

If the publication is distributed under the terms of Article $25 \mathrm{fa}$ of the Dutch Copyright Act, indicated by the "Taverne" license above, 
BBA 12185

\title{
THE CONTRIBUTION OF THE VARIOUS PHOSPHORYLATING STEPS IN THE RESPIRATORY CHAIN TO THE DINITROPHENOL-INDUCED ATPASE OF RAT-LIVER MITOCHONDRIA*
}

\author{
H. C. HEMKER \\ Laboratory of Physiological Chemistry, University of Amsterdam, \\ Amsterdam (The Netherlands)
}

(Received November I2th, I962)

\section{SUMMARY}

I. Accurate determinations of the shape of the curve relating the ATPase activity of rat-liver mitochondria with the dinitrophenol concentration have shown that a double optimum is obtained at about o.I $\mathrm{mM}$ and $0.2 \mathrm{mM}$ 2,4-dinitrophenol, respectively, at $\mathrm{pH} 7$.

2. Low concentrations of Amytal have a greater effect on the latter peak, whereas low concentrations of antimycin have a greater effect on the former.

3. The curves relating dinitrophenol-induced ATPase activity to concentration of antimycin or of Amytal show a clearly defined plateau indicating that only part of the ATPase is susceptible to each inhibitor. The effects of Amytal and antimycin are largely additive, and the ATPase is almost completely inhibited by Amytal and antimycin, together.

4. In the absence of dinitrophenol, both inhibitors induce an ATPase, the curves representing the ATPase activity in the presence and absence of dinitrophenol, respectively, running together at concentrations of the inhibitor equal to and higher than the amount giving the maximum ATPase activity in the absence of dinitrophenol.

5. A detailed study of the relationship between ATPase activity, measured in the presence and absence of dinitrophenol, and the concentration of the two inhibitors suggests that the dinitrophenol-induced ATPase at $\mathrm{pH} 7.0$ is made up of two enzyme systems: $62 \%$ by an Amytal-sensitive system inducible by dinitrophenol (optimal concn., $0.2 \mathrm{mM}$ ) or antimycin; $33 \%$ by an antimycin-sensitive system inducible by dinitrophenol (optimal concn., o.I mM) or Amytal.

6. It is proposed that the former system involves enzymes concerned in the first phosphorylation step and the second enzymes of the second phosphorylation step.

7. Various theories of oxidative phosphorylation are discussed in the light of these results.

* This work is part of the M.D. thesis of the author which was published in Dutch in April, I962 (ref. I). 
It is widely believed that the dinitrophenol-induced ATPase of rat-liver mitochondria represents a partial reversal and diversion of some of the reactions involved in oxidative phosphorylation, as first suggested about Io years ago by HuNTER ${ }^{2}$, Potter and Recknagel ${ }^{3}$ and Lardy and Wellman ${ }^{4}$. There is, however, considerable uncertainty whether there is one ATPase common to all phosphorylation steps, or, if they are different, what is the relative contribution of the three phosphorylating steps in the respiratory chain to the ATPase (see SLATER for a review).

On the basis of $\mathrm{pH}$-activity curves, MYers AND SLATER ${ }^{6,7}$ concluded that each of these steps contributed to the ATPase, the relative contribution depending upon the $\mathrm{pH}$ of the medium. Löw et al..$^{8-10}$, on the other hand, concluded that only the first phosphorylating step, i.e. that in the region of the pyridine nucleotides and flavoprotein, is involved.

The conclusions of MYERS AND SLATER were invalidated by the observations reported previously ${ }^{11}$. Löw's conclusions are largely based on the effects of Atebrin and on the inhibition by Amytal in the presence of Atebrin, on the assumption that Atebrin is a specific inhibitor of enzymes containing flavin as a prosthetic group, and that Amytal specifically inhibits between DPNH and flavoprotein. It has been shown ${ }^{12}$ that the first assumption is certainly not correct, while the conclusions drawn from the results with Amytal are complicated by the fact that antimycin, which does not inhibit the respiratory chain in the region of the pyridine nucleotides and flavoprotein, inhibits the dinitrophenol-induced ATPase in the presence of Atebrin.

For these reasons, it appeared necessary to re-investigate the question. This appeared particularly desirable in view of MITCHELL's ${ }^{13}$ ingenious theory of the mechanism of oxidative phosphorylation, which requires only one ATPase, and this is not specifically associated with any one phosphorylation step.

\section{AT Pase activity}

METHODS

This was measured as described by MYERS AND SLATER ${ }^{6}$. Where great precision was required in measuring the phosphate formed, the molybdenum blue was determined at $720 \mathrm{~m} \mu$ in a Zeiss spectrophotometer PMQ-II.

The reaction mixture contained $50 \mathrm{mM}$ Tris- $\mathrm{HCl}$ buffer, $75 \mathrm{mM} \mathrm{KCl}, 0.5 \mathrm{mM}$ EDTA, $2 \mathrm{mM} \mathrm{ATP}$, O.I M sucrose, and about $0.13 \mathrm{mg} / \mathrm{ml}$ mitochondrial protein in a volume of $x .5 \mathrm{ml}$. Freshly prepared rat-liver mitochondria ${ }^{6}$ were used in all the experiments. The uncoupling phenol was 2,4-dinitrophenol. The Amytal and antimycin were added in ethanolic solution. The final ethanol concentration did not exceed $3 \%$.

\section{Respiratory rates}

These were estimated by the Clark oxygen electrode in the apparatus des cribed elsewhere ${ }^{14}$. 


\section{RESULTS}

\section{Effect of dinitrophenol concentration}

On the assumption that if more than one dinitrophenol-induced ATPase is present, the different enzymes might be expected to differ in sensitivity to dinitrophenol, the effects of very small increments of dinitrophenol in the region giving a maximal ATPase activity ${ }^{11}$ were studied. Fig. I shows the results of a representative experiment. The biphasic curve was obtained in every one of $I_{5}$ experiments, and

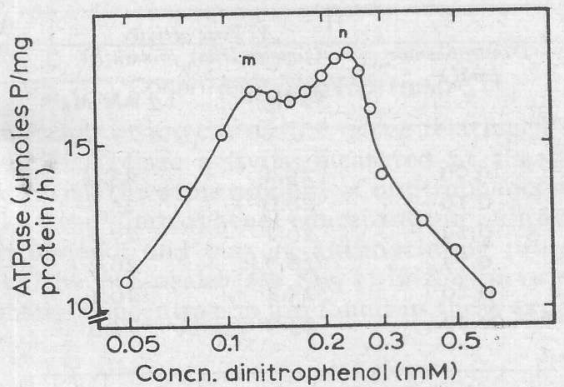

Fig. I. The ATPase-2,4-dinitrophenol concentration activity curve. $\mathrm{pH}$ 7.I.

the dinitrophenol concentrations giving the two optima were quite reproducible. However, the relative heights of the two peaks varied somewhat.

Fig. 2 gives further evidence that the double character of the activity-concentration curve shown in Fig. I is real. At each of the 4 dinitrophenol concentrations indicated, I6 separate measurements of the ATPase activity were made. Concen-

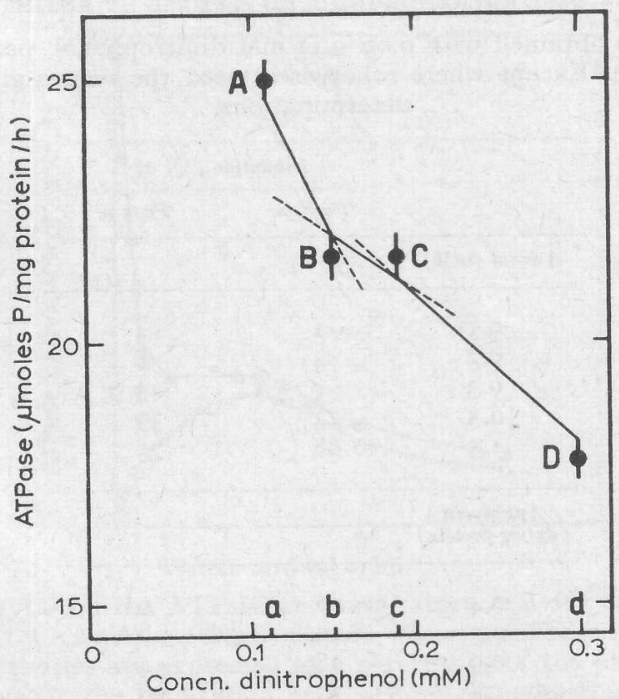

Fig. 2. A detailed study of 4 points in the ATPase-dinitrophenol concentration curve. Each point represents the mean of 16 measurements. $\mathrm{pH}$ 7.I. The length of the vertical line is $4 \times$ the standard error of the mean. 
trations $a$ and $c$ were chosen to give the two peaks. The points A-D show the mean values and the vertical lines indicate 4 times the value of the standard error of the mean. Even when twice the standard error is subtracted from $\mathrm{A}$ and $\mathrm{C}$, and added to $\mathrm{B}$ and $\mathrm{D}$, it is impossible to construct a smooth curve joining the points. It must

TABLE I

THE EFFECT OF $\mathrm{Mg}^{2+}$ on THE DINITROPHENOL-INDUCED ATPASE $\mathrm{pH}$ 7.0. The values given are the means of three experiments.

\begin{tabular}{ccc}
\hline \multirow{2}{*}{$\begin{array}{c}\text { Dinitrophenol } \\
\text { (mM) }\end{array}$} & \multicolumn{2}{c}{$\begin{array}{c}\text { ATPase activity } \\
\text { (umoles P/mg protein/h) }\end{array}$} \\
\cline { 2 - 3 } & No $\mathrm{Mg}^{2+}$ & $1.7 \mathrm{mM} \mathrm{Mg}^{2+}$ \\
\hline & & \\
0.06 & 25.2 & 23.9 \\
0.10 & 26.6 & 25.8 \\
0.12 & 26.2 & 27.2 \\
0.17 & 26.7 & 26.2 \\
0.20 & 25.4 & 26.1 \\
0.22 & 23.9 & 24.5 \\
\hline
\end{tabular}

be concluded that the curves illustrated in Figs. I and 2 are composite, being made up of more than one activity-concentration curve.

Table I shows that added $\mathrm{Mg}^{2+}$ had very little effect on the dinitrophenolinduced ATPase at all concentrations of dinitrophenol between 0.06 and $0.22 \mathrm{mM}$.

\section{TABLE II}

iNHIBITION OF THE DINITROPHENOL-INDUCED ATPASE BY ANTIMYCIN AND AMYTAL

$\mathrm{pH}$ 6.9-7.0. Peak $m$ was obtained with 0.09-0.I I $\mathrm{mM}$ dinitrophenol, peak $n$ with 0.18-0.20 $\mathrm{mM}$ dinitrophenol ( $c f$. Fig. I). Except where otherwise stated the values given are the means of 3 determinations.

\begin{tabular}{|c|c|c|}
\hline & \multicolumn{2}{|c|}{ Inhibition $(\%)$ at } \\
\hline & Peak $m$ & Peak $n$ \\
\hline \multicolumn{3}{|l|}{ Amytal (mM) } \\
\hline O.I & $-I$ & 4 \\
\hline 0.2 & 4 & 8 \\
\hline 0.3 & $7 \pm 2^{\star}$ & $23 \pm I$ \\
\hline 0.5 & 24 & 39 \\
\hline I. 5 & 68 & 71 \\
\hline \multicolumn{3}{|l|}{$\begin{array}{c}\text { Antimycin } \\
(\mu \mathrm{g} / \mathrm{mg} \text { protein) }\end{array}$} \\
\hline 0.4 & 12 & o \\
\hline 0.5 & 13 & 2 \\
\hline 0.9 & 28 & -4 \\
\hline I. 8 & 33 & 28 \\
\hline
\end{tabular}

* Mean \pm standard error of mean for 5 estimations. 


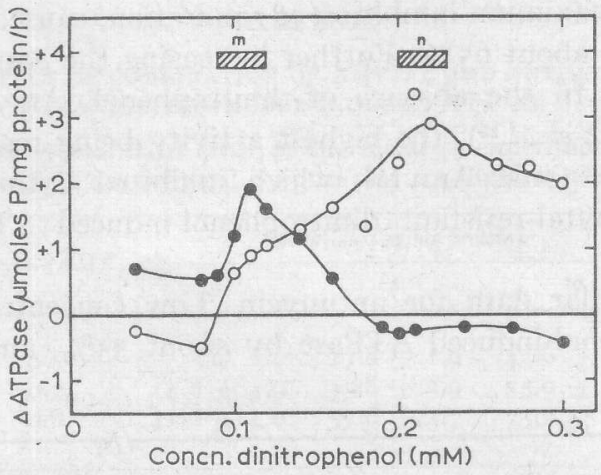

Fig. 3. The effect of Amytal and antimycin on the curve relating ATPase activity and dinitrophenol concentration. $\bigcirc-0$, ATPase activity measured at the dinitrophenol concentration indicated minus the activity with the same amount of dinitrophenol and $0.3 \mathrm{mM}$ Amytal.

ATPase activity measured at the dinitrophenol concentration indicated minus the activity with the same amount of dinitrophenol and $0.25 \mu \mathrm{g}$ antimycin/mg protein. The squares $m$ and $n$ indicate the region in which the two peaks (see Fig. I) in the curve relating ATPase activity to dinitrophenol concentration are found in these experiments.

\section{Effect of Amytal and antimycin on the dinitrophenol-induced ATPase}

Table II shows that low concentrations of Amytal (less than $0.5 \mathrm{mM}$ ) have a greater effect on the ATPase induced by about $0.2 \mathrm{mM}$ dinitrophenol (Peak $n$ in Fig. I) than that induced by about o.I mM dinitrophenol (Peak $m$ in Fig. I). Antimycin, on the other hand, had a greater effect on Peak $m$. The same point is illustrated in another experiment in Fig. 3.

The effect of different concentrations of Amytal is shown in greater detail in Fig. 4. Increasing the concentration up to about I mM, which is about the concen-

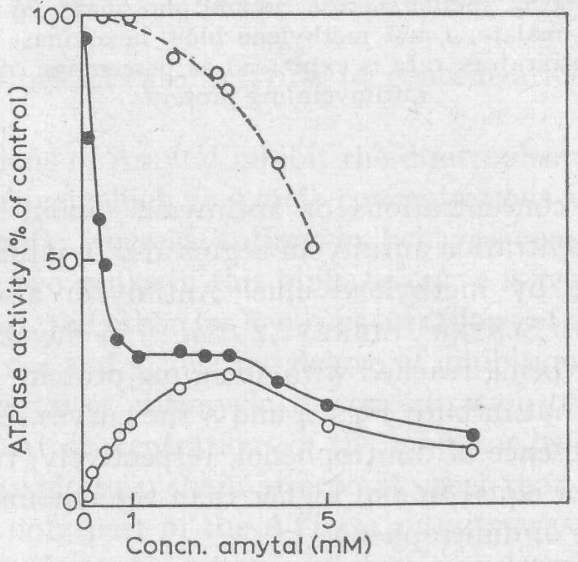

Fig. 4. The effect of Amytal on the ATPase and respiratory activity of rat-liver mitochondria. - ATPase induced by I.2 mM 2,4-dinitrophenol; $\mathrm{O}-\mathrm{O}$. ATPase in the absence of dinitrophenol. (The ATPase activities are expressed as a percentage of the uninhibited dinitrophenolinduced ATPase.) I $5 \mathrm{mM} \mathrm{KCl,} 2 \mathrm{mM}$ EDTA, $50 \mathrm{mM}$ Tris- $\mathrm{HCl}$ buffer $(\mathrm{pH} 7), 5 \mathrm{mM} \mathrm{MgCl}$, $50 \mathrm{mM}$ sucrose, $60 \mathrm{mM}$ succinate, $20 \mathrm{mM}$ phosphate, $20 \mathrm{mM}$ glucose, hexokinase, 0.I $\mathrm{mM}$ ATP and about I mg mitochondrial protein. Expressed as percentage of uninhibited system. 
tration required for maximum inhibition of respiration, caused increasing inhibition of the ATPase, up to about $65 \%$. Further increasing the Amytal concentration to $3 \mathrm{mM}$ had no effect. In the absence of dinitrophenol, Amytal itself induces an ATPase ( $c f$. SiEkEvitz et al. ${ }^{15}$ ), the highest activity-being reached at about $3 \mathrm{mM}$. Concentrations above $3 \mathrm{mM}$ Amytal, which inhibited both the Amytal-induced ATPase and the Amytal-resistant dinitrophenol-induced ATPase, also inhibited succinate oxidation.

Fig. 5 shows similar data for antimycin. Low concentrations of antimycin* inhibit the dinitrophenol-induced ATPase by about $33 \%$, and there is no further

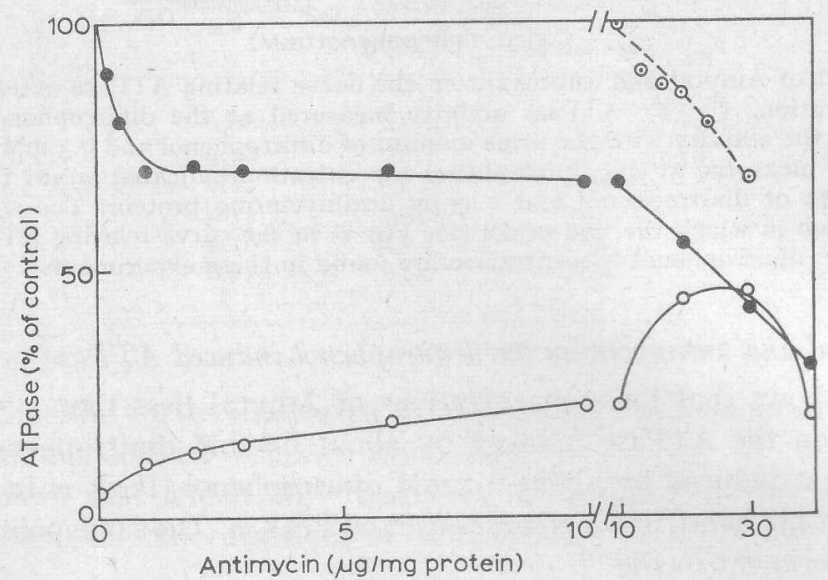

Fig. 5. The effect of antimycin on the ATPase and respiratory activity of rat-liver mitochondria. - ATPase induced by $1.2 \mathrm{mM}$ 2,4-dinitrophenol; O-O. ATPase in the absence of antimycin. (The ATPase activities are expressed as a percentage of the uninhibited dinitrophenol-induced ATPase.) $---O$, rate of respiration in a system containing $15 \mathrm{mM} \mathrm{KCl}, 2 \mathrm{mM}$ EDTA, $50 \mathrm{mM}$ Tris- $\mathrm{HCl}(\mathrm{pH} 7), 5 \mathrm{mM} \mathrm{MgCl}_{2} .50 \mathrm{mM}$ sucrose, $20 \mathrm{mM}$ phosphate, $20 \mathrm{mM}$ glucose, o.I mM ATP, $20 \mathrm{mM}$ pyruvate, $20 \mathrm{mM}$ malate, I $\mathrm{mM}$ methylene blue, hexokinase and about I $\mathrm{mg} / \mathrm{ml} \mathrm{mito-}$ chondrial protein. The respiratory rate is expressed as percentage of that obtained with Io $\mu \mathrm{g}$ antimycin/mg protein.

inhibition until high concentrations of antimycin (about Io $\mu \mathrm{g} / \mathrm{mg}$ protein) are reached, at which concentration antimycin begins also to inhibit the rate of oxidation of pyruvate + malate by methylene blue. Antimycin also induces an ATPase activity ( $c f$. Myers AND SLATER ${ }^{7}$, SiEkEvitz et al..$^{15}$ ) in the absence of dinitrophenol, the maximum activity being reached with $30 \mu \mathrm{g} / \mathrm{mg}$ protein.

It is noteworthy that in both Figs. 4 and 5 the curves representing the ATPase in the presence and absence of dinitrophenol, respectively, run together at concentrations of the inhibitor equal to and higher than the amount giving the maximum ATPase in the absence of dinitrophenol.

Table III shows that the inhibitory effects of Amytal and of antimycin are largely independent of one another. In other experiments, $87 \%$ inhibition of the

* In this laboratory, about $0.05^{-0 . I} \mu \mathrm{g}$ antimycin/g mitochondrial protein has been found sufficient for maximal inhibition of the respiration of rat-liver mitochondria (SLATER, unpublished; cf. ESTABROOK ${ }^{16}$ ). 
TABLE III

EFFECT OF COMBINATION OF AMYTAL AND ANTIMYCIN ON DINITROPHENOL-INDUCED ATPASE

The values give the mean \pm standard error of the mean ( 4 experiments) of the percentage inhibition of the ATPase induced by $0.12 \mathrm{mM} 2,4$-dinitrophenol at $\mathrm{pH} 7.0$.

\begin{tabular}{lccc}
\hline \multirow{2}{*}{ Amytal $(\mathrm{mM})$} & \multicolumn{3}{c}{ Antimycin $(\mu \mathrm{g} / \mathrm{mg}$ protein) } \\
\cline { 2 - 4 } & 0 & \multicolumn{1}{c}{ Io } \\
\hline 0 & 0 & $27.8 \pm 1.9$ & $42.6 \pm 2.6$ \\
0.2 & $\mathrm{I} 4.8 \pm 3.9$ & $35.8 \pm 3.9$ & $55.0 \pm 2.6$ \\
0.8 & $41.8 \pm 1.0$ & $57.6 \pm 3.7$ & $73.2 \pm 3.2$
\end{tabular}

dinitrophenol-induced ATPase could be obtained by addition of both inhibitors.

It should be noted that the effects of Amytal and antimycin on the dinitrophenol-induced ATPase described here do not agree well with the reports of similar experiments in the literature. ALDRIDGE AND PARKER ${ }^{17}$ found no inhibition of the dinitrophenol-induced ATPase by $0.8 \mathrm{mM}$ Amytal and SiEKEvitz et al. ${ }^{15}$ found practically no inhibition by I.0 mM Amytal, only $40 \%$ by $4.0 \mathrm{mM}$ Amytal, and no inhibition by $1.0 \mu \mathrm{g}$ antimycin (the concentration of protein was not stated). No explanation can be offered for these differences.

\section{DISCUSSION}

\section{Multiple nature of dinitrophenol-induced ATPase of rat-liver mitochondria}

The following evidence has been brought forward indicating that the dinitrophenol-induced ATPase of rat-liver mitochondria preparations involves more than one enzyme system:

(I) The curve relating ATPase activity to concentration of dinitrophenol is biphasic (Figs. I and 2).

(2) Low concentrations of Amytal inhibit the dinitrophenol-induced ATPase to a greater extent at relatively high $(0.2 \mathrm{mM})$ concentrations of dinitrophenol than at relatively low (o.I mM), whereas antimycin behaves conversely (Table II). In other words, one of the two peaks in this biphasic curve is readily inhibited by low concentrations of Amytal, the other by low concentrations of antimycin (Fig. 3).

(3) The curves (Figs. 4 and 5) relating degree of inhibition of the dinitrophenolinduced ATPase by Amytal or antimycin to concentration of the inhibitor show a clearly defined plateau. At concentrations of the inhibitor below those which could be shown to affect the respiratory chain at a point other than that with which they "specifically" combine, only part of the ATPase activity was sensitive to these inhibitors. The inhibitory effects of the two inhibitors were largely independent of one another (Table III) and the ATPase was almost completely inhibited by Amytal + antimycin. This observation indicates that the inhibitory effect of antimycin and Amytal is not simply due to the reduction of components of the respiratory chain $\left(\right.$ e.g. $\left.\mathrm{DPN}^{+}\right)$by endogenous substrate in the presence of these respiratory inhibitors, reduction of the chain having been shown by WADKINS AND LEHNINGER ${ }^{18}$ and 
CHEFURKA ${ }^{19}$ to cause inhibition of the dinitrophenol-induced ATPase. If this were the case, either Amytal or antimycin would be expected to have the maximum effect. In fact the inhibition by Io $\mu \mathrm{g}$ antimycin $/ \mathrm{mg}$ protein $(42.6 \%)$ and $0.8 \mathrm{mM}$ Amytal $(4 \mathrm{I} .8 \%)$ were almost additive $(73.2 \%$ by the two inhibitors together).

These results appear to establish that at least two systems are present, an Amytal-sensitive and an antimycin-sensitive, the former requiring rather higher concentrations of dinitrophenol than the latter.

\section{Nature of the two dinitrophenol-induced ATPases}

Three possibilities were considered:

(I) The mitochondria present in the preparation used in these experiments are probably derived from both the two main cell types in liver, the parenchymatous cells forming about $84 \%$ of the total and the Kupfer cells about I5\% (see ref. 20 ). It is conceivable that the two types of mitochondria might differ in their susceptibility to dinitrophenol which depends upon the solubility of the uncoupler in the mitochondrial lipid ${ }^{11}$. However, this is very unlikely to be the explanation of the results reported here, since one peak of the activity-dinitrophenol concentration curve was found to be more sensitive to antimycin and the other more sensitive to Amytal. It is known that these inhibitors act in the same way upon mitochondria of very different origin ${ }^{21-25}$.

(2) The mitochondrial preparation probably contains some damaged mitochondria, the ATPase of which has been shown by SIEKEViTz et al. ${ }^{15}$ to be less sensitive to Amytal. If these damaged mitochondria also required a greater concentration of dinitrophenol for maximum activity, the results illustrated in Fig. I and Table II might be obtained. In that case, however, one might expect that the ATPase activity would be affected by the addition of $\mathrm{Mg}^{2+}$, since SIEKEVITZ et al. ${ }^{15}$ have shown that even after slight damage, the addition of $\mathrm{Mg}^{2+}$ stimulates the ATPase even in the presence of dinitrophenol. Table I shows no effect of $\mathrm{Mg}^{2+}$.

(3) The Amytal-sensitive ATPase represents the reversal of the first phosphorylation step of the respiratory chain, and the antimycin-sensitive step the reversal of the second step.

While it is not claimed that the third explanation is established by the experimental results, it appears at present to be the simplest, and provides a satisfactory basis for a further discussion of the results.

The results are also in good agreement with HüLsMANn's ${ }^{26}$ suggestion that both uncouplers and certain respiratory inhibitors (indicated by $\varnothing$ ) act by reaction with a high-energy intermediate of oxidative phosphorylation. Writing the general mechanism of oxidative phosphorylation suggested by SLATER ${ }^{27}$ with $I$ in place of C (cf. Chance AND Williams ${ }^{28}$ )

$$
\begin{gathered}
\mathrm{AH}_{2}+\mathrm{B}+\mathrm{I} \rightleftharpoons \mathrm{BH}_{2}+\mathrm{A} \sim \mathrm{I} \\
\mathrm{A} \sim \mathrm{I}+\mathrm{ADP}+\mathrm{P}_{\mathbf{i}} \rightleftharpoons \mathrm{A}+\mathrm{I}+\mathrm{ATP}
\end{gathered}
$$

where $\mathrm{AH}_{2}$ and $\mathrm{B}$ are adjacent members of the respiratory chain, HÜLSMANN ${ }^{26}$ 
proposed ${ }^{\star}$ that both uncouplers and respiratory inhibitors of the type of antimycin and Amytal reacted according to Eqns. 3 and 4

$$
\begin{gathered}
A \sim \mathrm{I}+\varnothing \rightarrow \mathrm{A}+\varnothing-\mathrm{I} \\
\varnothing-\mathrm{I} \rightleftharpoons \varnothing+\mathrm{I}
\end{gathered}
$$

In his view, the difference between an uncoupler and these respiratory inhibitors is a quantitative one, depending upon the relative ease of the decomposition of $\varnothing-I$ by Reaction 4 . With uncouplers this occurs readily so that the free I necessary for the hydrogen-transfer reaction (Eqn. I) is regenerated. Thus uncouplers allow respiration to proceed, but by promoting the decomposition of $\mathrm{A} \sim \mathrm{I}$ prevent the synthesis of ATP (Eqn. 2). However, Eqn. 4 is reversible so that higher concentrations of $\varnothing$ will bind I, thereby inhibiting respiration (see also ref. II). The binding of I to form a stable $\varnothing-I$ compound is the predominant reaction with the respiratory inhibitors.

According to this theory the dinitrophenol-induced ATPase is explained by the reverse of Eqn. 2, followed by Reactions 3 and 4. Thus, high concentrations of dinitrophenol cause inhibition of the dinitrophenol-induced ATPase, which is the reason for the optimum in the activity-dinitrophenol concentration curve $e^{6,9,11,26}$. Any compound which binds I will also inhibit the dinitrophenol-induced ATPase. HÜLSMANN ${ }^{26}$ assumed that this involved three different enzyme systems, corresponding to the three phosphorylating steps. He proposed that Amytal combined with $I_{1}$, concerned in the first phosphorylation step, while antimycin combined with $I_{2}$, concerned in the second phosphorylation step.

\section{Relative contribution of the tro dinitrophenol-induced ATPases}

It is clear by a comparison of Figs. 4 and 5 that the Amytal-sensitive ATPase makes a greater contribution to the total dinitrophenol-induced ATPase than the antimycin-sensitive. In the absence of dinitrophenol; both inhibitors themselves induce an ATPase, which is inhibited by higher concentrations. It has already been pointed out that the maximum value of the Amytal- or antimycin-induced ATPase is equal to the amount of the dinitrophenol-induced ATPase resistant to these inhibitors. Thus, it appears that both antimycin and Amytal are able to induce the ATPase which they do not inhibit. Like other uncouplers, in higher concentrations they inhibit the ATPase which they induce. Thus, low concentrations of Amytal inhibit the oxidation of pyridine nucleotide-linked substrates and the dinitrophenol-induced ATPase by reacting with $\mathrm{A} \sim \mathrm{I}_{1}$, to give the stable Amytal- $\mathrm{I}_{1}$; in high concentrations it induces an ATPase by reacting with $\mathrm{A}^{\prime} \sim \mathrm{I}_{2}\left(\mathrm{~A}^{\prime}\right.$ is a component of the respiratory chain in the second phosphorylating step) to form the unstable Amytal- $\mathrm{I}_{2}$; in still higher concentrations it binds $\mathrm{I}_{2}$, thereby inhibiting succinate oxidation, the Amytal-resistant dinitrophenol-induced ATPase and the Amytal-induced ATPase. Antimycin acts in an analogous fashion forming the stable

* In HÜLSMANN's formulation, an additional component X ( $c f$. refs. 28 and 7 ) was required for the reaction between $\mathrm{A} \sim \mathrm{I}$ and $\varnothing$. This is irrelevant for the argument developed here. 


\section{TABLE IV}

ATPASE ACTIVITY INDUCIBLE BY ANTIMYCIN AND AMYTAL ALONE AND INHIBITION OF DINITROPHENOL-INDUCED ATPASE Each value is the mean \pm standard error of the mean (number of experiments) of the ATPase
activity expressed as percentage of the maximum dinitrophenol-induced ATPase. pH 6.8-7.2.

\begin{tabular}{|c|c|c|c|}
\hline & \multicolumn{3}{|c|}{ ATPase activity } \\
\hline & Antimycin & Amytal & Sum \\
\hline Induced & $60.8 \pm 1.9(8)$ & $33 . I \pm 0.8(7)$ & $93.9 \pm 2.1$ \\
\hline $\begin{array}{l}\text { Inhibition of dinitrophenol- } \\
\text { induced ATPase } \\
\text { Mean }\end{array}$ & $\begin{array}{l}64.5 \pm 1.3(4) \\
62.0 \pm 1.4(\mathrm{I} 2)\end{array}$ & $\begin{array}{l}33.0 \pm \mathrm{I} .7(4) \\
33.2+0.8(\mathrm{II})\end{array}$ & $\begin{array}{l}97.5 \pm 2.2 \\
95.2 \pm 1.6\end{array}$ \\
\hline Mean & & $33.2 \pm 0.0(11)$ & \\
\hline
\end{tabular}

antimycin- $\mathrm{I}_{2}$, and the unstable antimycin- $\mathrm{I}_{1}$, which is nevertheless formed in sufficiently large amounts by high concentrations of antimycin to inhibit the various reactions which require $I_{1}$.

The data from a number of experiments summarized in Table IV show that $95 \%$ of the total ATPase activity induced by dinitrophenol can be accounted for by the two enzyme systems:

(I) $62 \%$ by an Amytal-sensitive system induced by dinitrophenol (optimal concn., $0.2 \mathrm{mM}$ ) or antimycin;

(2) $33 \%$ by an antimycin-sensitive system induced by dinitrophenol (optimal concn., o.I mM) or Amytal. The remaining $5 \%$ can be considered to be within the experimental error.

The relative sensitivity of the dinitrophenol-induced ATPase to antimycin and Amytal found in this study does not differ greatly from the relative sensitivity of the $\mathrm{P}_{\mathbf{i}}$-ATP exchange reaction to these inhibitors. Löw et al. ${ }^{8}$ found $55 \%$ inhibition by $2 \mathrm{mM}$ Amytal and $37 \%$ by antimycin; HüLSMANN ${ }^{26}$ found $46 \%$ inhibition by $0.6 \mathrm{mM}$ Amytal and $26 \%$ by antimycin. Löw et al. ${ }^{8}$ also reported that antimycin occasionally potentiated the effect of Amytal.

The $\mathrm{pH}$-activity curve of the maximum ATPase published previously, with maximum at $\mathrm{pH} 6.8$, will be dominated by the Amytal-sensitive enzyme system. The $\mathrm{pH}$-optimum of the Amytal-resistant ATPase is close to 7.5 (Fig. 6). It is

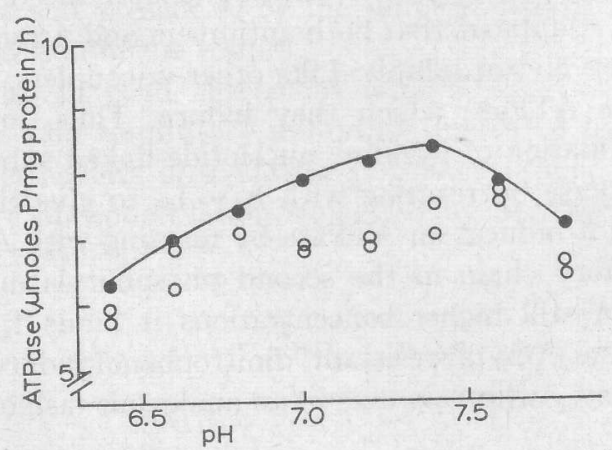

Fig. 6. The $\mathrm{pH}$ optimum of the Amytal ( $1 \mathrm{mM}$ )-resistant dinitrophenol-induced ATPase. At each $\mathrm{pH}$, three concentrations of dinitrophenol close to the optimal concentration were tested. The highest ATPase activity is indicated by 
clear that the two $\mathrm{pH}$ optima lie too close together to allow an identification of two enzymes on this basis alone.

\section{Mechanism of action of dinitrophenol}

In I945, LARDY AND ELVEHJEM ${ }^{29}$ suggested that nitrophenols and other compounds which inhibited various energy-requiring functions without inhibiting respiration acted either by allowing oxidation to proceed without phosphorylation, or by catalysing the hydrolysis of an intermediate phosphate compound. The second possibility was further developed by LARDY AND WELLMAN ${ }^{4,30}$ and others ${ }^{31-33}$. The intermediate phosphate compound was thought of as an enzyme $\sim$ phosphate compound which could react with dinitrophenol to give a dinitrophenol-enzyme compound which then decomposes liberating the free enzyme. In I953, SLATER ${ }^{27}$ suggested that dinitrophenol reacted with an intermediate formed prior to the intervention of phosphate $(\mathrm{A} \sim \mathrm{I}$ in Eqn. I), and this is now generally accepted (see SlAteR $^{5}$ for a review). As already discussed, HÜLSMANN ${ }^{26}$ extended this theory to take account of the inhibition by higher concentrations of dinitrophenol of respiration and of the dinitrophenol-induced ATPase. This theory satisfactorily accounts for the findings of the present paper.

The alternative theory of LARDY AND ELVEHJEM ${ }^{29}$, viz. that dinitrophenol allows oxidation to proceed without phosphorylation, has recently been developed in specific terms by LINDBERG AND ERNSTER and their co-workers in Stockholm. The most recent version of this theory ${ }^{34}$ explains the dinitrophenol-induced ATPase by the reaction sequence

$$
\begin{gathered}
\mathrm{ATP}+\mathrm{X} \quad \rightleftharpoons \mathrm{X} \sim \mathrm{P}+\mathrm{ADP} \\
\mathrm{X} \sim \mathrm{P}+\mathrm{fpH}_{2} \rightleftharpoons \mathrm{Pi}+\mathrm{fpH} \sim \mathrm{X} \\
\mathrm{fpH} \sim \mathrm{X}+\mathrm{DPN}^{+}+\mathrm{OH}^{-} \rightleftharpoons \mathrm{fp}+\mathrm{X}+\mathrm{DPNH} \\
\mathrm{DPNH}+\mathrm{fp}+\mathrm{H}^{+} \stackrel{(\text { dinitrophenol) }}{\longrightarrow} \mathrm{DPN}^{+}+\mathrm{fpH}_{2}
\end{gathered}
$$

This theory, which is largely founded on the inhibition of the dinitrophenol-induced ATPase by Amytal in the presence of Atebrin, does not explain (a) the incompleteness of the inhibition by Amytal in the absence of Atebrin (Fig. 4); (b) the inhibition of the ATPase by antimycin in the presence of Amytal (Table III), since antimycin cannot promote the reduction of flavoprotein by endogenous substrate in the presence of Amytal; (c) the inhibition of the dinitrophenol-induced ATPase by excess dinitrophenol. We are unable to agree with the recent comment by ERNSTER ${ }^{35}$ that his view of the mode of action of dinitrophenol has received valuable support by our studies ${ }^{11}$.

MiTCHELL ${ }^{13}$ proposes that dinitrophenol acts by catalysing the exchange of $\mathrm{H}^{+}$ and $\mathrm{OH}^{-}$across the mitochondrial membrane, thereby allowing the operation of an ATPase situated in this membrane which is impermeable from one side to $\mathrm{H}^{+}$ and from the other to $\mathrm{OH}^{-}$. Although this theory successfully explains much of the data on oxidative phosphorylation, it does not explain the inhibition by excess 
dinitrophenol. Moreover, there is no necessity for more than one ATPase in MITCHELL's theory.

Our conclusion that the dinitrophenol-induced ATPase is made up of two enzyme systems lies between that of MYERS AND SLATER ${ }^{6,7}$, who proposed that all three phosphorylating steps contributed to the reaction, and that of Löw et al. ${ }^{8}$ who proposed that only the first phosphorylation step is involved. We agree with Löw et al. that the first step is quantitatively the most important and that there is no evidence that the third step makes any contribution, but we consider that the second step makes a not inconsiderable contribution (about half that of the first). The relationship of the two enzyme systems to the three ATPases obtained by PENNIALL ${ }^{36}$ in salt-free medium is still obscure.

\section{ACKNOWLEDGEMENTS}

The author is very grateful to Prof. Dr. E. C. SLATER for many valuable suggestions and fruitful discussions, and thanks Miss M. VAN UfFelen and Miss W. Nuwenhof for their accurate technical assistance.

This work was supported in part by the U.S.P.H. grant RG 6569 .

\section{REFERENCES}

1 H. C. HEMKER, Het mechanisme van de werking van ontkoppelende fenolen op de ademhalingsketenfosforylering, M.D. thesis, University of Amsterdam, Klein Offset Drukkerij, Amsterdam, I962. 2 F. E. Hunter, in B. Glass, Phosphorus Metabolism, Vol. I, Johns Hopkins Press, Baltimore, I95 r, P. 297.

3 V. R. Potter and R. O. Recknagel, in B. Glass, Phosphorus Metabolism, Vol. I, Johns Hopkins Press, Baltimore, I951, p. 377.

4 H. A. Lardy and H. Wellman, J. Biol. Chem., 201 (I953) 357.

5 E. C. Slater, Symp. on Intracellular Respiration: Phosphorylating and Non-Phosphorylating Reactions, Proc. 5th Intern. Congr. Biochem., Moscow, I96I, Vol. 5, Pergamon Press, London, I963, p. 325 .

6 D. K. Myers and E. C. Stater, Biochem. J., 67 (I957) $55^{8}$.

D. K. Myers and E. C. Slater, Biochem. J., 67 (I957) 572.

8 H. Löw, P. Siekevitz, L. Ernster and O. Lindberg, Biochim. Biophys. Acta, 29 (I958) 392.

9 H. Löw, Biochim. Biophys. Acta, 32 (I959) I.

10 H. Löw, Biochim. Biophys. Acta, 32 (I959) II.

11 H. C. HeMker, Biochim. Biophys. Acta, 63 (1962) 46.

12 H. C. Hemker and W. C. Hülsmann, Biochim. Biophys. Acta, 44 (1960) I75.

13 P. Mitchell, Nature, I9I (I96I) I44.

14 H. C. Hemker, Biochim. Biophys. Acta, 60 (Ig62) 646.

15 P. Stekevitz, H. Löw, L. Ernster and O. Lindberg, Biochim. Biophys. Acta, 29 (I958) 378.

16 R. Estabrook, Biochim. Biophys. Acta, 6o (1962) 236.

17 W. N. AIDRIDGE AND V. H. PARKer, Biochem. J., 76 (1960) 47.

18 C. L. Wadkins and A. L. Lehninger, J. Biol. Chem., 234 (I959) 68I.

10 W. Chefurka, Can. J. Biochem. Physiol., 38 (I960) I 195.

20 G. A. Gates, K. S. Henley, H. M. Pollard, E. Schmidt and F. W. Schmidt, J. Lab. Clin. Med., 57 (I96r) I82.

21 K. Ahmad, H. G. Schneider and F. M. Strong, Arch. Biochem., 28 (I950) 28 I.

22 V. R. Potter And A. E. Reif, J. Biol. Chem., I94 (I952) 287.

23 L. G. ABoon, Am. J. Physiol., I76 (I954) 247.

24 P. Borst, Een biochemisch onderzoek over mitochondriën geisoleerd uit een ascitescel tumor, M.D. thesis, University of Amsterdam, Jacob van Campen, Amsterdam, I96I.

thesis, University of Amsterdam, Jacob van Campen, Amst. Exptl. Cell Res., Suppl., 3 (I955) I24.
25 L. Ernster, O. Jalling, H. Löw and O. LindBerG, J. E.
26 W. C. HÜlsmann, Over het mechanisme van de ademhalingsketen-phosphorylering, M.D. thesis, University of Amsterdam, Klein Offset Drukkerij, Amsterdam, I958.

27 E. C. Slater, Nature, I72 (I953) 975. 
28 B. Chance and G. R. Williams, J. Biol. Chem., 217 (1955) 429.

${ }^{29}$ H. A. Lardy and C. A. Elvehjem, Ann. Rev. Biochem., I4 (I945) I.

${ }^{30} \mathrm{H}$. A. LaRdy and H. Wellman, J. Biol. Chem., I95 (I952) 215.

31 D. E. Green, Biol. Rev. Cambridge Phil. Soc., 26 (I95I) 4Io.

32 K. H. Lee and J. J. Eiler, J. Biol. Chem., 203 (I953) 7r9.

${ }^{33}$ C. Cooper and A. L. Lehninger, J. Biol. Chem., 224 (r957) 547, 56I.

34 L. ERnster, Symp. on Intracellular Respiration: Phosphorylating and Non-Phosphorylating Reactions, Proc. 5th Intern. Congr. Biochem., Moscow, r96I, Vol. 5, Pergamon Press, London, I963, P. II 5 .

${ }^{35}$ L. ERnSTER, Symp. on Intracellular Respiration: Phosphorylating and Non-Phosphorylating Reactions, Proc. 5th Intern. Congr. Biochem., Moscow, I96r, Vol. 5, Pergamon Press, London, I963, P. I 49.

36 R. Penniali, Biochim. Biophys. Acta, 44 (1960) 395.

Biochim. Biophys. Acta, 73 (1963) 3II-323 